\title{
Diagnostics of the structural failure of sports hall external wall layers
}

\author{
Leopold Kruszka ${ }^{1, *}$, and Pawel Muzolf ${ }^{1}$ \\ ${ }^{1}$ Faculty of Civil Engineering and Geodesy, Military University of Technology, 2 Urbanowicza St., \\ 00-908 Warsaw, Poland.
}

\begin{abstract}
The paper presents the diagnostics of the technical condition of the external layers of the sports hall walls. Structural failures related to construction defects themselves constitute a relatively small percentage (4.1\% in $2017,5.05 \%$ in 2014-2017 [1]), although the main reason for them is the lack of maintaining technological rigors $(76.9 \%$ in $2017,68.4 \%$ in 2014-2017 [1]). The presented and described case study of the technical condition of the newly built sports hall does not refer to structural failure, but to the reduction of the risk of that failure as a result of non-compliance with construction technology, in particular, in relation to the external walls. Contrary to the design, the walls of the sports hall were made of aerated concrete. According to the declaration of a designer, the contractor neither consulted the changes with the designer nor gain the acceptance of the designer for using aerated concrete instead of the primary proposed and designed brick structure. In addition, aerated concrete curtain walls with a height of about $4.5 \mathrm{~m}$ were made without any wall connectors. This resulted in a risk of a structure failure involving the collapse of its curtain walls. The technological requirements for the repairing of the elements of supporting walls as well as the diagnostic process of the other damaged finishing cladding of external walls are also provided in this paper.
\end{abstract}

\section{Introduction}

The article presents a case study of the diagnostics of the technical condition of the external layers of the sports hall walls. The case describes, in particular, the risk of structural failure involving the possibility of collapsing of the outer layer of the newly built sports hall building walls on its two façades - the west façade (marked with blue arrows in Fig. 1) and the south façade (marked with red arrows in Fig. 1) [2]. The causes of the revealed damages and physical defects of the building are presented. Particularly cracking of external walls, loosening of the plasters and ceramic tiles from the external claddings of the building, including clinker tiles on the retaining wall at the construction site are observed.

\footnotetext{
${ }^{*}$ Corresponding author: leopold.kruszka@,wat.edu.pl
} 


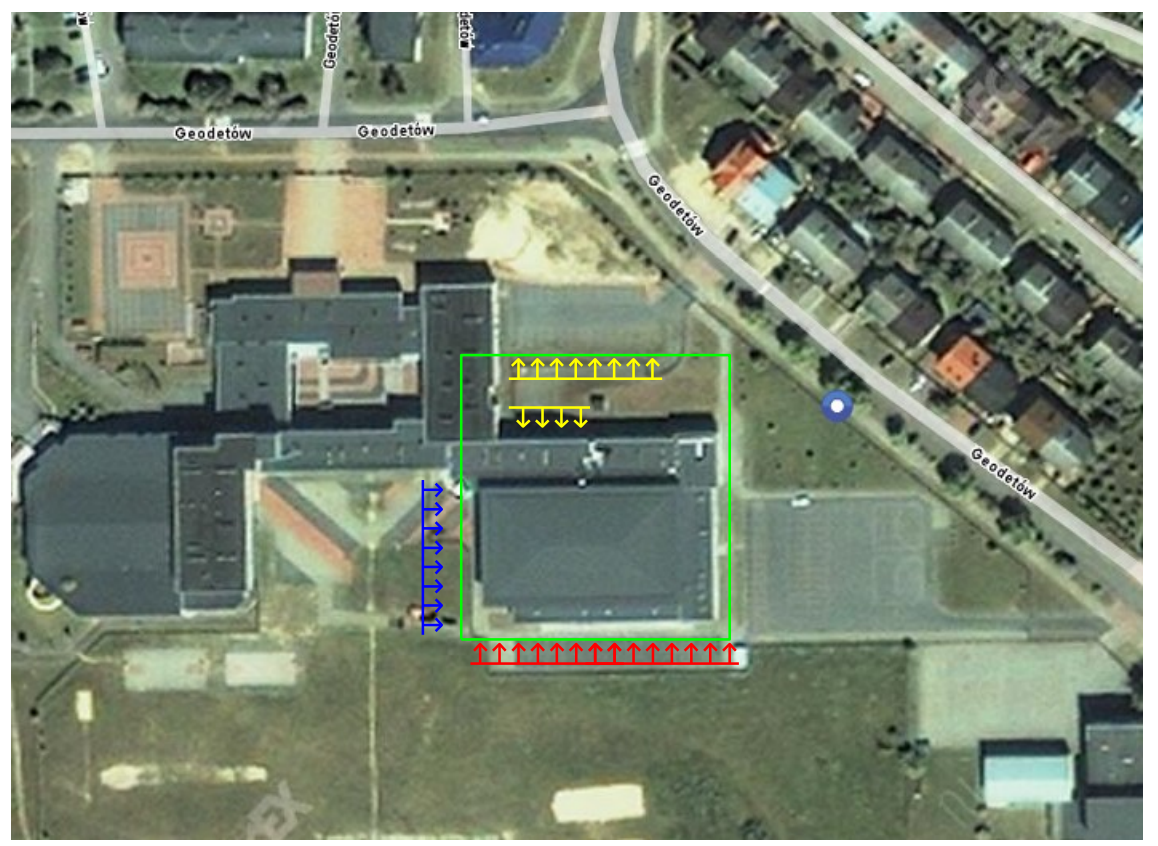

Fig. 1. Top view of the building being the case study subject - description in the text, www.zumi.pl.

The proposals for removing physical defects have been provided, along with determining the scope of necessary construction works necessary to bring the building into the proper technical condition in accordance with applicable regulations and civil engineering experiences and to eliminate abovementioned structural failure. These issues are important for a wide selection of building technologies and materials to create durable and affordable repairing projects and construction works [3-6] in our climate zone, taking into account the inconvenience of these repair works.

\section{Description of the technical condition of the building}

For the purpose of performing a full and correct assessment of the scope of physical defects and damages, the available documentation, including the design and the operational documentation of the building, was firstly analysed. After a site inspection combined with a detailed visual inspection of the damages as well as after the analysis of the technical documentation of the building, a plan of diagnostic activities was prepared. The crucial element of this plan was the proper selection of the localization and techniques of testing the structural elements of the building. The test results made it possible to correctly identify the causes of damage and propose the possible solutions of its repair. In addition to the selection of repair work solutions themselves, the technological requirements for the preparation of damaged elements of the load-bearing structure for its repair were also indicated.

The main reason for the risk of a structural failure was the incorrect execution of selfsupporting walls on two façades, i.e. from the west and south sides of this sports hall building [2].The south wall of the sports hall was built as a sandwich structure. It was constructed contradictory to the rules of the civil engineering practise and the technical conditions for this type of building structures. The structural inner layer of this wall was $2.4 \mathrm{~cm}$ thick and it was made of the autoclaved aerated concrete blocks (according to the registry of embedded materials). It had welds of too great thickness - the maximum thickness of the weld in the made outcrop was $24 \mathrm{~mm}$, which should not exceed $15 \mathrm{~mm}$ (Fig. 2). In 
turn, the wall covering layer was made of $12 \mathrm{~cm}$ thick cellular concrete blocks. It should be emphasized that the use of such material for the covering layer is not recommended. The insulation layer was made of two Styrofoam boards with a thickness of $4 \mathrm{~cm}$ each. Unfortunately, they were not fixed to the structural layer, but loosely inserted into the air gap of $12 \mathrm{~cm}$. The loose arrangement of Styrofoam panels indicated that there were too few (or none at all) steel connectors that would have enabled a proper interconnection between these two layers of the wall.

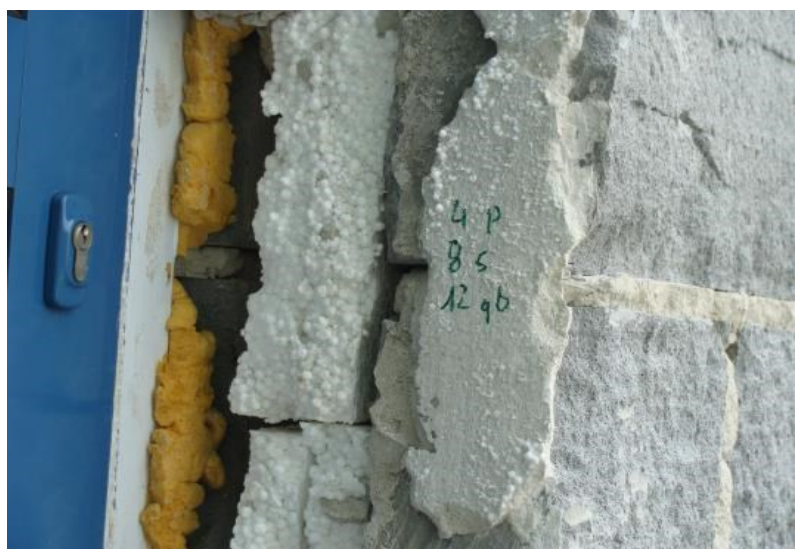

Fig. 2. Layer system of the outer multi-layer and self-supporting wall - description in the text.

The lower edge of the aerated concrete wall was at a height of about $25 \mathrm{~cm}$ above ground level. This is too low because the technical construction requirements of the wall made of cellular concrete blocks provide that this height should be at least $50 \mathrm{~cm}$. At the bottom of this wall, no drainage slots were found - Fig. 3.

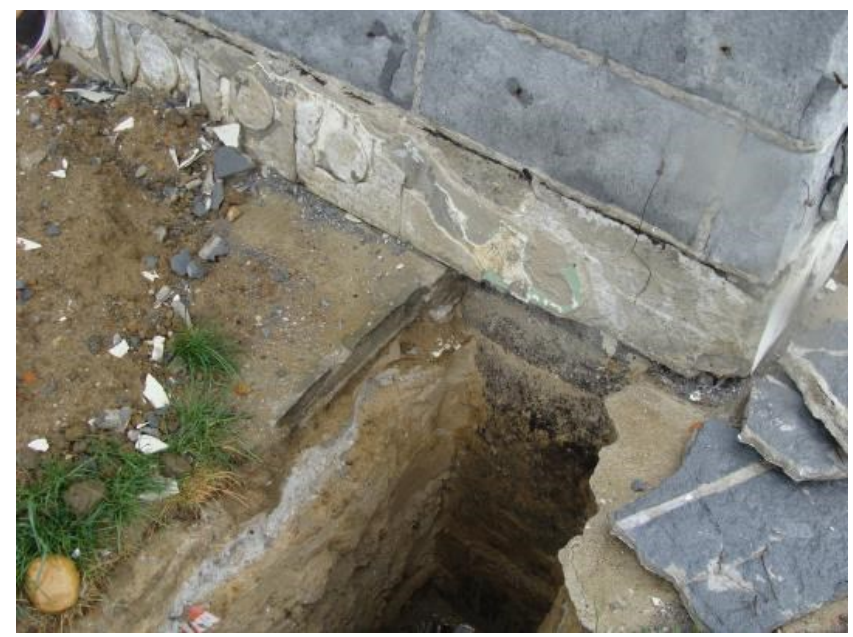

Fig. 3. A detailed view of the foundation of the wall covering layer.

The abovementioned defects of this masonry structure caused by undue performance of the builder resulted in the formation of distinct sloping cracks in the outer casing layer. This proves improper behaviour of this wall layer system - Fig. 4. 
a)

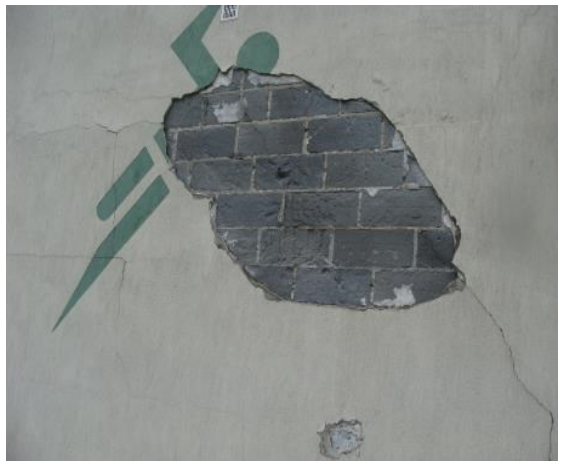

b)

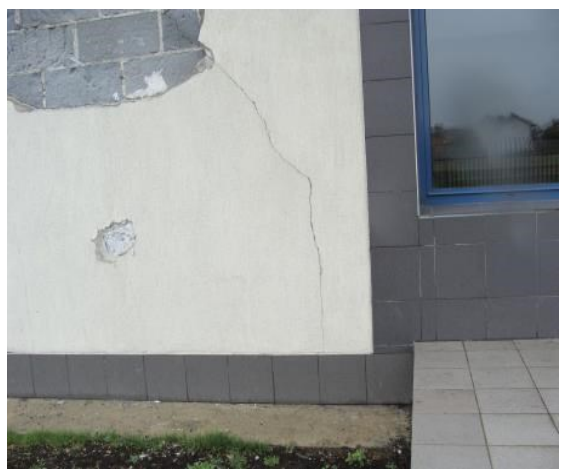

Fig. 4. Examples of visible cracks in the cover layer on the southern façade.

Based on a test pit of the foundations of the building, it was found that the above cracks did not result from the process of uneven settlement of the foundations, because the foundation walls were not damaged - Fig. 5.

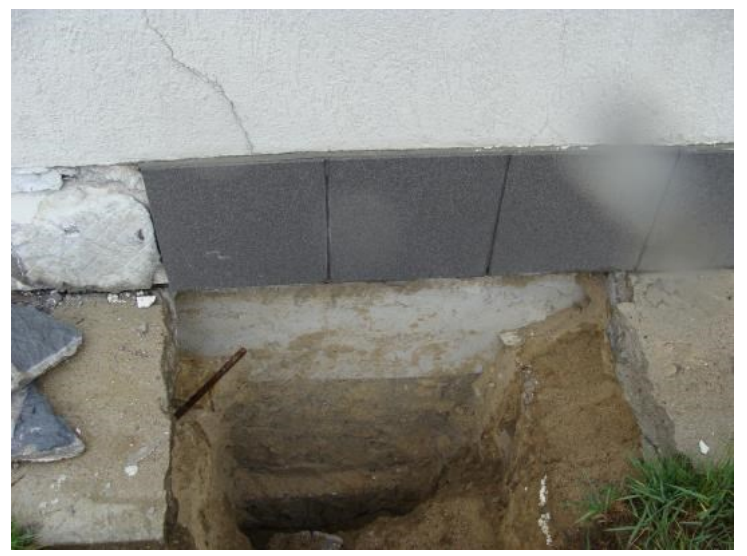

Fig. 5. Test pit of the building foundations.

An analogous situation occurred on the west façade - in the lower part no signs of wall connectors were observed (Fig. 6). Based on this site uncover it was established that the wall was made as a layered wall in the form of two layers of cellular concrete units with a thickness of $24 \mathrm{~cm}$ each, with a thermal polystyrene insulation layer of $4 \mathrm{~cm}$ thick placed in between them. Carrying out the aerated concrete curtain walls with a height of about $4.5 \mathrm{~m}$, without the wall ties, caused a risk of a structural failure involving the possibility of its collapse. The structure of this wall was not considered as self-supporting because the number of applied wall connectors were insufficient [8-11]. The observed damages were the result of the mistakes of the contractor. The wall layer system was incompatible with the design and asbuilt documentation. According to the statement of the designer, the contractor neither consulted nor obtained the consent of the designer to the use of the cellular concrete instead of the building ceramics. 


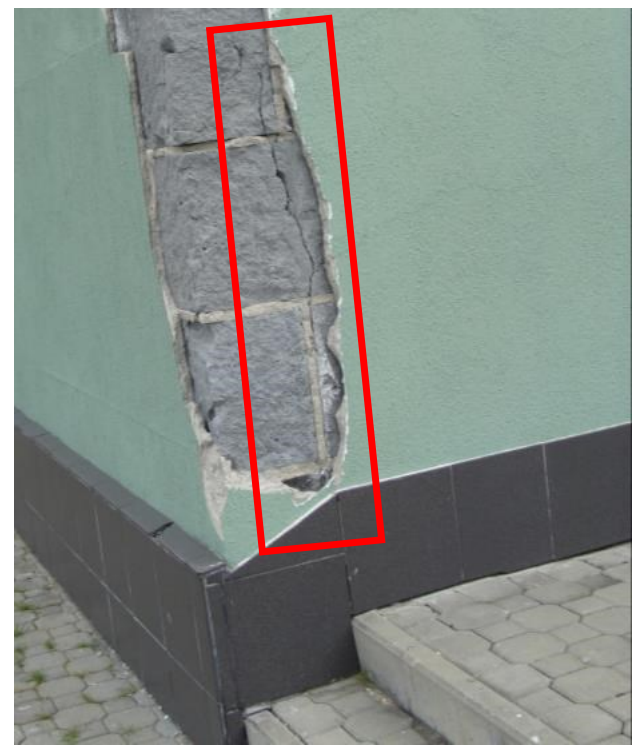

Fig. 6. Damage to the lower part of the western façade wall.

Another significant diagnosed damage (removable damage) was the spalling of the plaster coats - Fig. 7. These damages occurred both on the south and on the west façades of this building. The spalling of the plasters on the façades was the result of their improper execution. No application of any joint layer was found. In addition, the applied plastering was very absorbent, which in combination with the execution of the outer layer of walls with air concrete resulted in their so-called "spalling" due to weather conditions.

a)

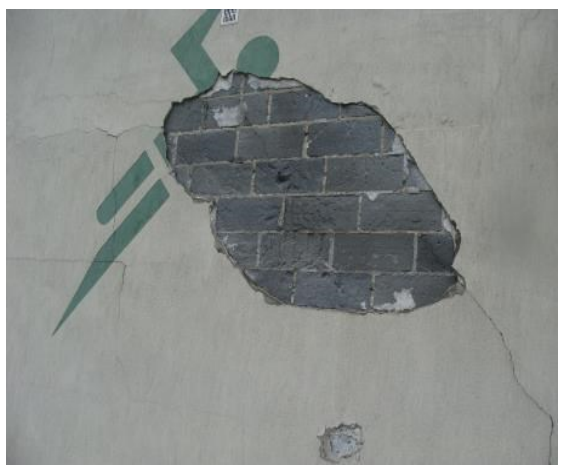

b)

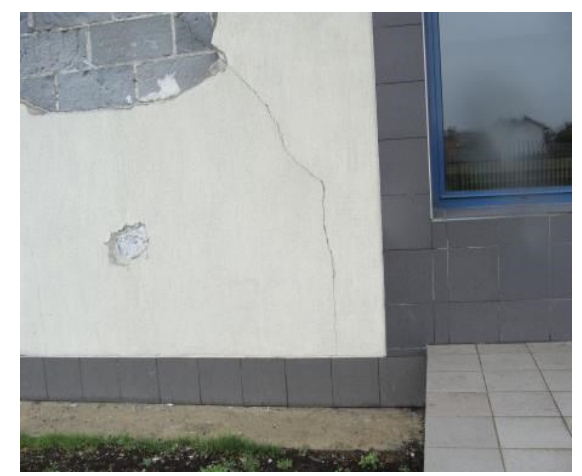

Fig. 7. Examples of the spalled plasters: a) on the south façade, b) on the west façade.

An additional factor causing soaking of the façade walls and their plastering was improper preparation of flashings (leaks due to the use of plastic plugs) and the unsuitable slope in the top parts of these walls - Fig. 8. The described damage to the façade sandwich walls was significant and constitutes of removable physical defects. They not only significantly worsened the aesthetic state of the building but also significantly reduced the utility value of this part of the building. Furthermore, they were a direct hazard to the safety of the use of the hall. The area next to the building was excluded from use due to the danger of falling of large fragments of plaster or walls $[12,13]$. 
a)

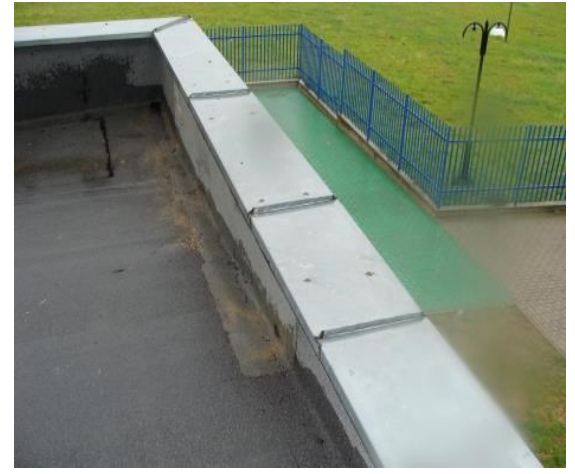

b)

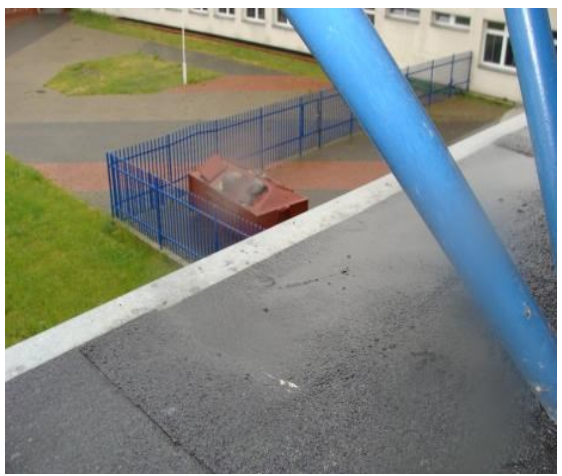

Fig. 8. Improper ending of façade walls: a) use of plastic dowels for fixing flashings, b) retention of rainwater due to improper slopes.

The retaining wall and the basement wall at the exit from the building, marked in yellow with yellow arrows (Fig. 1), were covered with clinker tiles with joint sealing compound. The adoption of such a solution in connection with the careless execution of the barriers, the lack of expansion joints, the improper arrangement of the tiles on the mortar as well as leaving free spaces beneath them, caused both weeping and loosening of these tiles due to rainwater - Fig. 9. It should be emphasized that the phenomenon of cyclic freezing and thawing in the winter period played particularly significant role in this issue.

a)

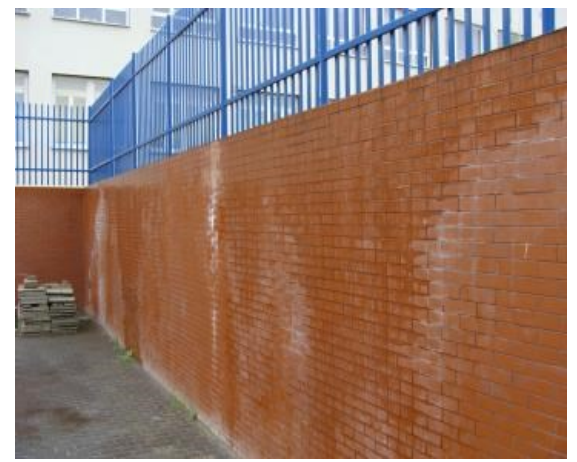

c)

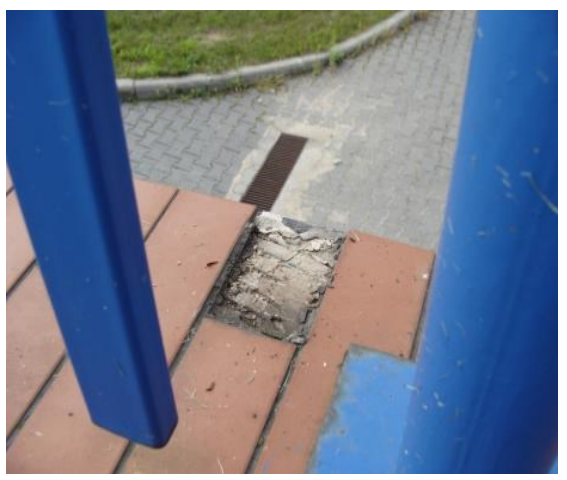

b)

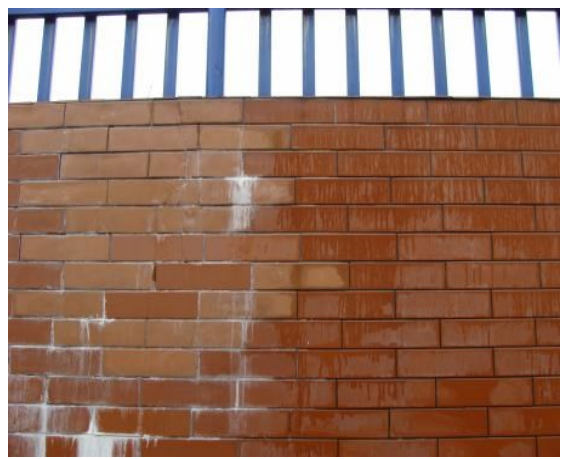

d)

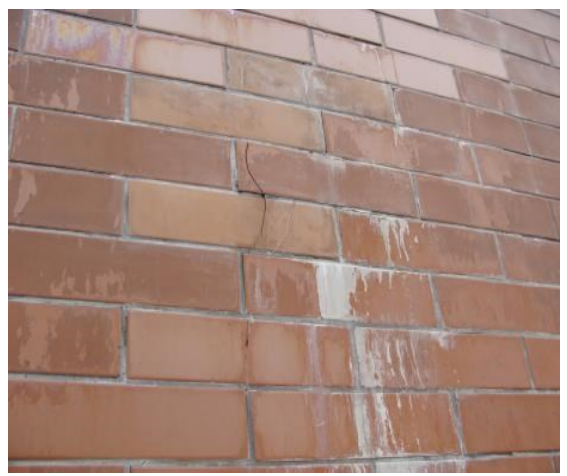

Fig. 9. Damage to the cladding of the retaining wall made of clinker tiles: a) general view of the cladding with visible wet weeping and traces of washed calcium, b) clear runoffs of the rainwater on the clinker tiles of the cladding, c) inspection of the cladding of the upper part of the retaining wall - visible spaces in the adhesive mortar, d) weaning and cracking of the clinker tile cladding. 
The described damages of the clinker cladding of the analysed retaining wall constituted of significant removable physical defects because they not only significantly worsen the aesthetic condition of the building but also significantly reduced the operational value of this structural element.

Another group of defects are damages to ceramic claddings on the external walls, the stairs and terraces next to the building. Figure 10 shows the scheme of the site with the location of individual damages. Figure 11 presents examples of these damages that essentially consist of cracking and detaching of ceramic tiles.

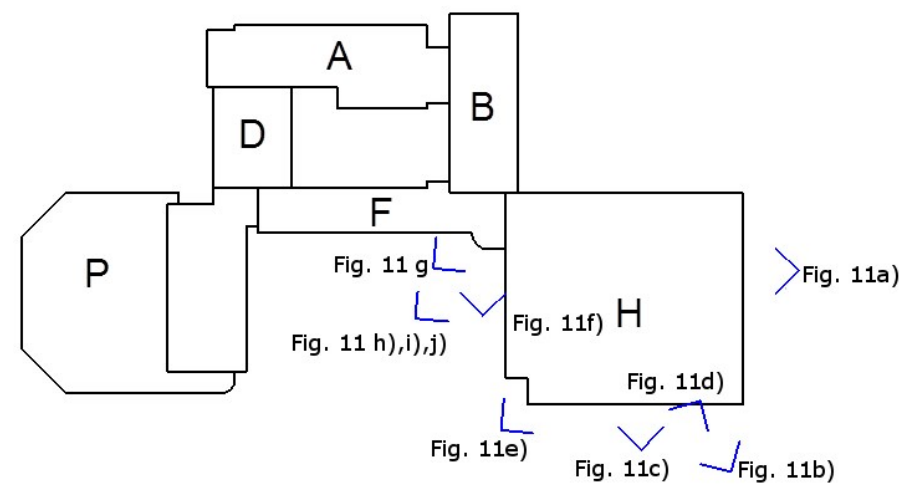

Fig. 10. Location of ceramic damage to façade claddings.

a)

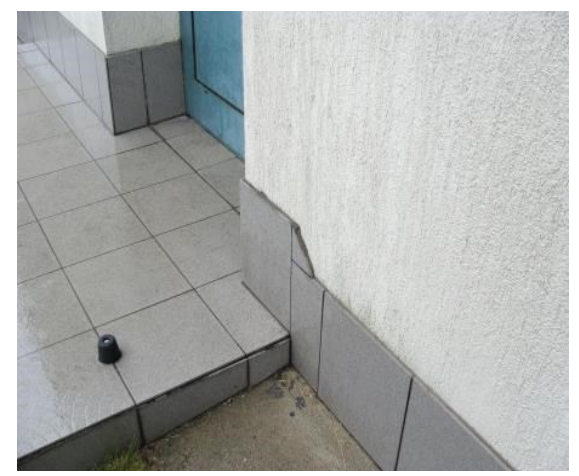

c)

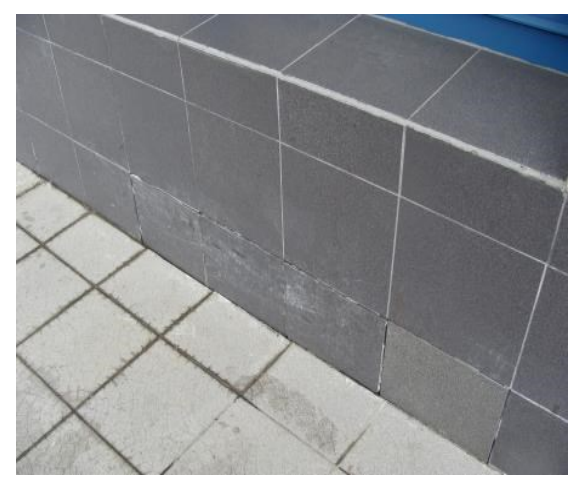

b)

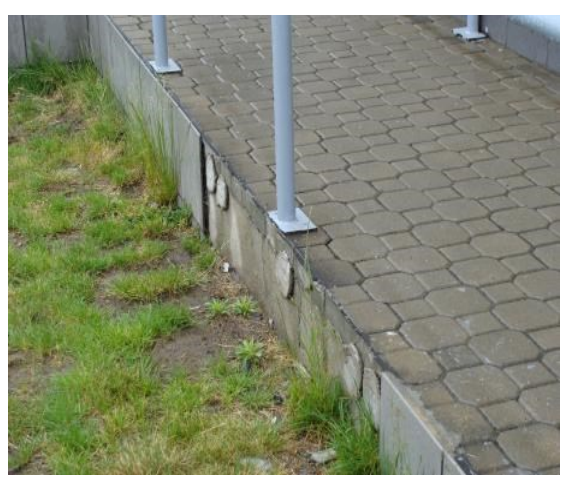

d)

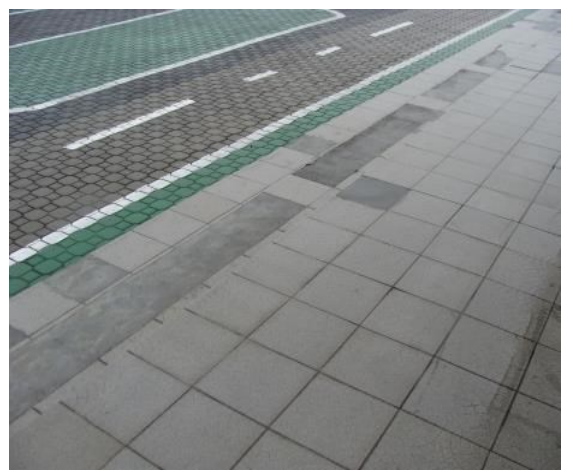


e)

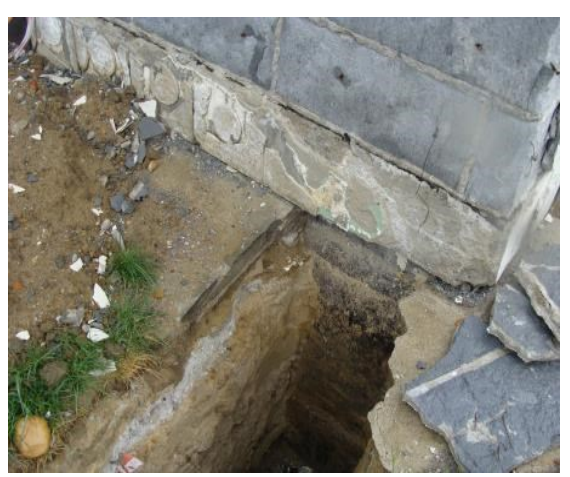

g)

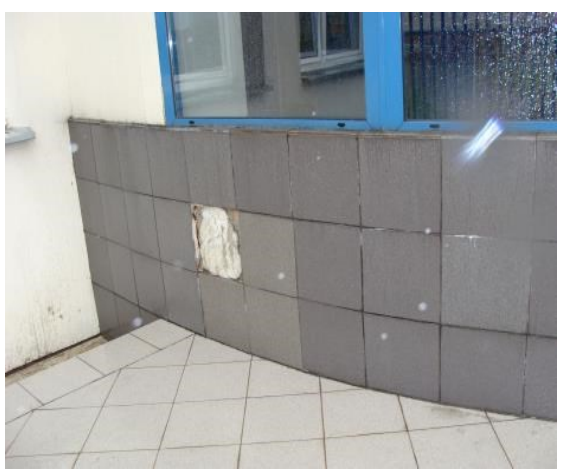

i)

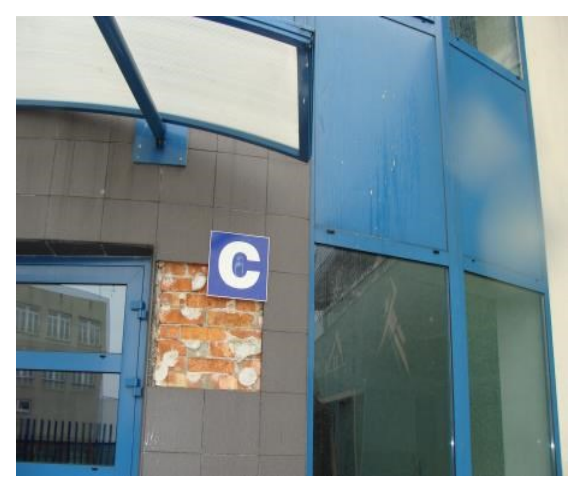

f)

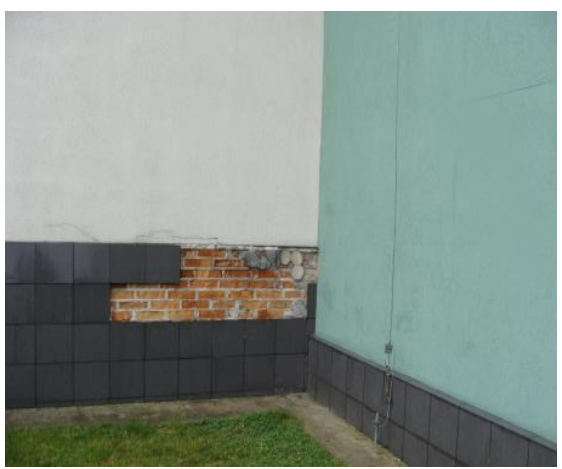

h)

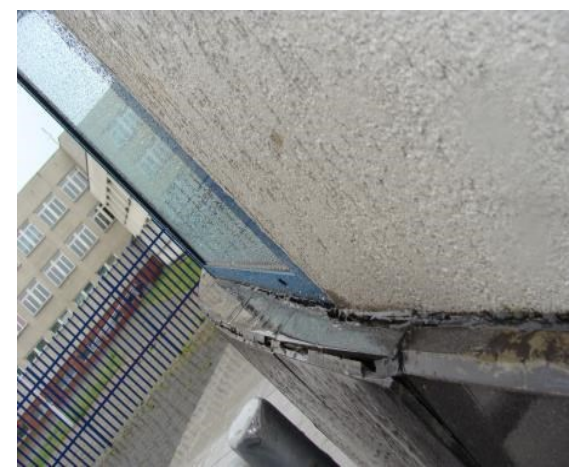

j)

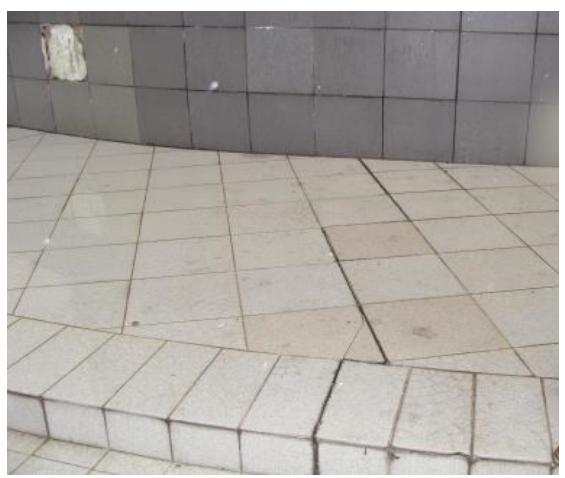

Fig. 11. a) $\div$ j) Examples of the ceramic damage to the cladding of the façades and the entrance stairs.

Damage to ceramic claddings was the result of careless arrangement of them with the method of so-called "pancakes" which resulted in free fall of water under the tiles. This implied especially the damage to the mortar and the lower layers of the claddings in winter conditions. In addition, the facings made did not possess appropriate flashings that would have protected façade elements against rainwater (Fig. $11 \mathrm{c}, \mathrm{f}, \mathrm{g}, \mathrm{h}, \mathrm{i}$ ). Therefore, the protection of the lower part of the façade, as well as the cladding at the entrances to the building against rainwater drainage, had to be reconsidered through the use of flashings. In addition, the layout of the tiles in the dilation area is incorrect (Fig. $11 \mathrm{j}$ ). This shows that the works have been carried out without care and accuracy.

Leaks in the roof slope result primarily from improper fitting of inlets of rainwater drainage system - Fig. 12. Local damage to flashings of cornices was also observed. 
a)

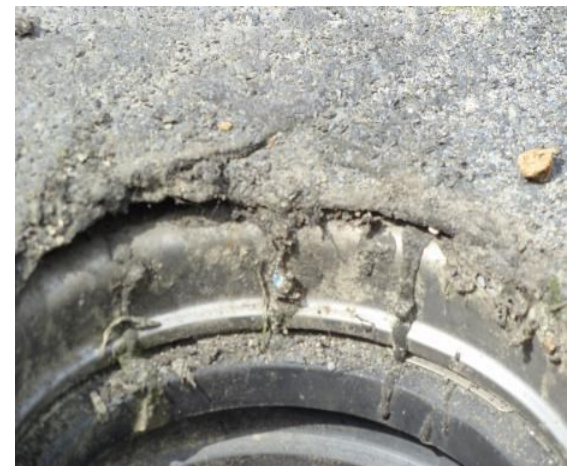

b)

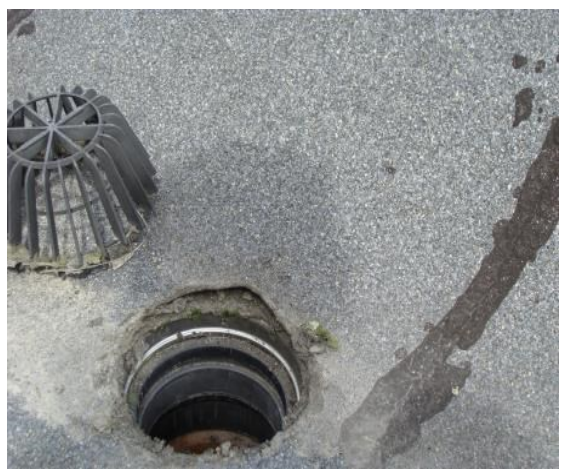

Fig. 12. Examples of improper installation of rainwater drainage system with roofing paper.

Damage to the installation of rainwater inlets constituted removable however significant defects because it allowed rain water to enter the building. This resulted in accelerated technical wear of internal elements of the structure. Leaks in the chimney seats and local damage to flashings caused local water marks on the ceilings - Fig. 13. These physical defects had to be removed after repairing the entire roofing and painting the ceiling.

a)

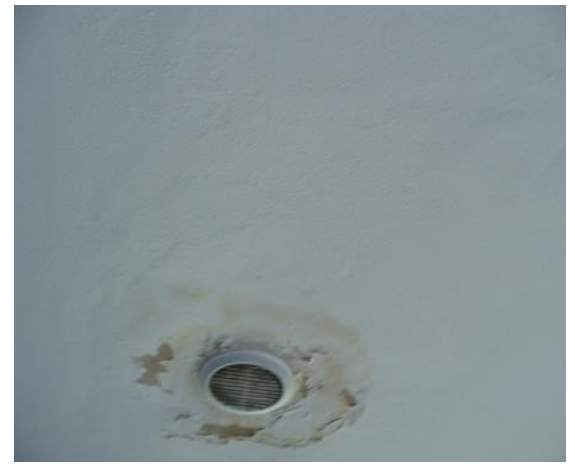

b)

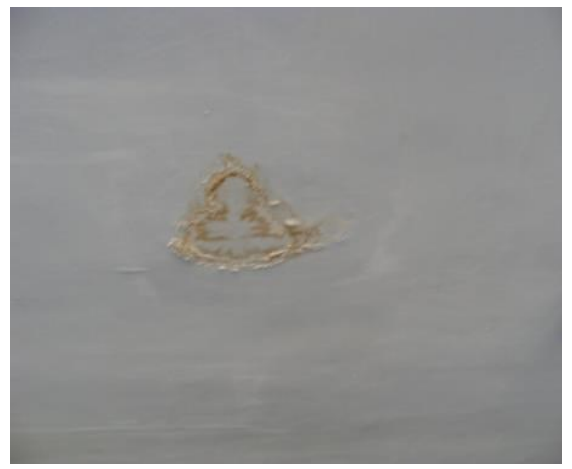

Fig. 13. Examples of water marks on ceilings.

\section{Proposal packet of repair systems and solutions}

\subsection{Repairing of damaged external walls}

In the first stage, the entire plaster coating should be removed from the whole facade of the southern and western building. Damaged - cracked walls of the building should be strengthened by surface reinforcement.

The lack of anchoring between the covering layer and the construction layer on the lower part of the building is a great hazard for a structural failure. It is absolutely necessary to tie these layers with special connectors. These connectors should be anchored mechanically or chemically in the structural wall to a minimum depth of $12 \mathrm{~cm}$ (half the thickness of the structural wall). This depth and the number of connectors (at least $4 \mathrm{pcs} / \mathrm{m}^{2}$ ) should be precisely determined after choosing the anchoring system. The use of the special Helifix DryFix universal connectors was proposed as a solution. Made of stainless steel self-screwing connector does not require the use of resin or other mortars. It is installed by screwing it, using a special, patented adapter, into a previously prepared pilot hole (it is proposed to create a pilot hole only through the protective layer). This method does not cause additional stress 
to the masonry structure. Due to the large slenderness combined with the low strength of the cover layer, it is proposed to use $50 \mathrm{~cm}$ long connectors, screwed in at an angle of $30^{\circ}$ alternately at $20 \mathrm{~cm}$ spacing with a horizontal offset of $6 \mathrm{~cm}+$ weld thickness of $\sim 7.5 \mathrm{~cm}$. The proposed mechanical pinning and anchoring solution of the curtain wall is shown in Fig. 14. The proposed spacing of connectors is $90 \mathrm{~cm}$ horizontally and $37.5 \mathrm{~cm}$ vertically, which gives an average of three connectors per square meter, or 6 pieces of connectors per $\mathrm{m}^{2}$. The use of Helifix DryFix solution in the form of intersecting DryFix tie will additionally ensure fastening of the existing insulation layer.

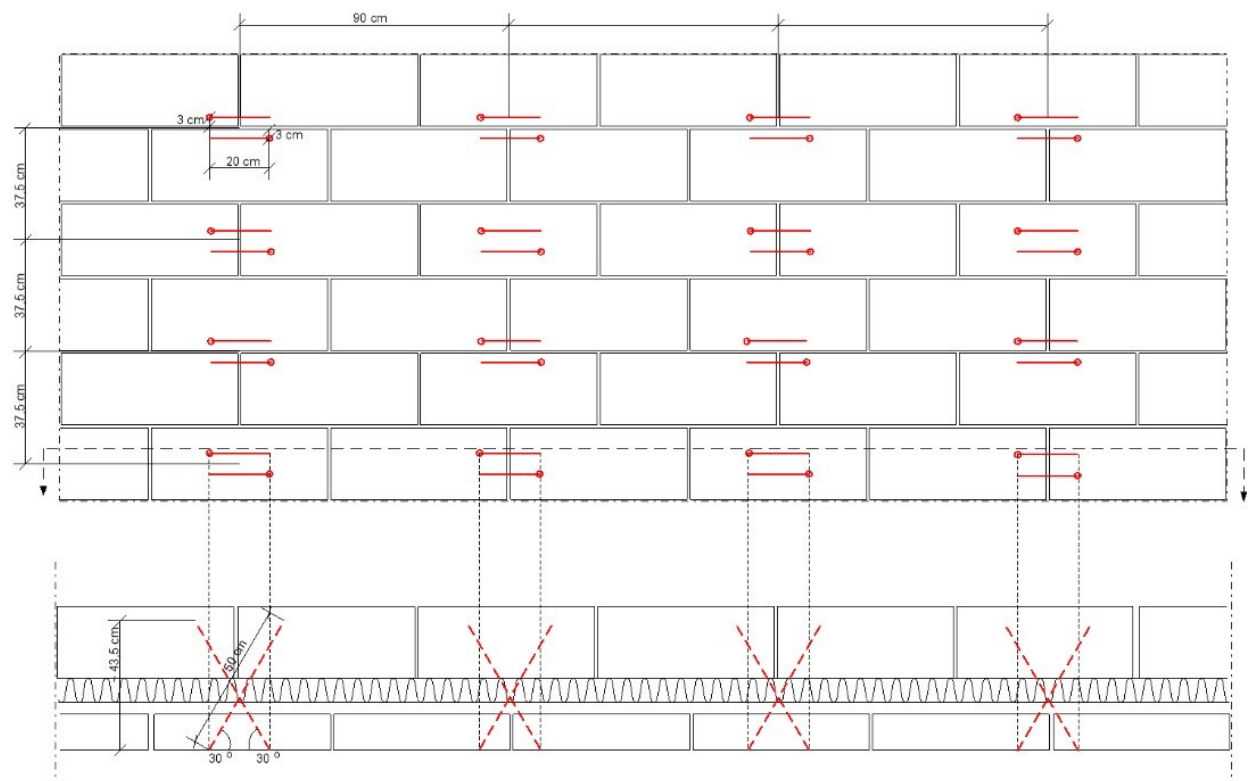

Fig. 14. Scheme of the proposed mechanical pinning and anchoring solution of the casing layer with the load bearing leaf of the wall of the low building part.

After fixing the masonry layers together, holes should be made in the curtain wall to provide ventilation of the air gap. Their minimum area is $15 \mathrm{~cm}^{2}$ per linear meter of the wall. The next step is to create a layer protecting the damaged curtain wall. For this purpose, it is proposed to make a cover of foamed polystyrene with a finish in the form of wall insulation using the "light-wet" method. The minimum thickness of the additional styrofoam layer should be $4 \mathrm{~cm}$, while the polystyrene should be fastened both by gluing and with mechanical fasteners.

An alternative solution is the dismantling of the curtain wall made of aerated concrete blocks (on the part of the lower base of the hall) together with the insulation layer made of styrofoam boards. Then, these layers should be rebuilt. It would be advisable to make a new layer of thermal insulation made of mineral wool mounted to the structural layer by means of special fasteners so called "wall dowels for thermal insulation". Due to the low height of the bottom of the wall from the ground level, it is recommended to make a curtain wall made of solid brick. A very important issue is to ensure the proper attachment of wall layers. The minimum number of connectors is $4 \mathrm{pcs} / \mathrm{m}^{2}$. When using this solution, openings protecting the ventilation of the air gap can be obtained by performing unfinished joints or by installing special grids. In order to obtain the proper thermal insulation coefficient, also in this variant, insulation with a $4 \mathrm{~cm}$ layer of polystyrene should be performed.

With regard to the western wall of the hall (west elevation), visible damage in the lower part results also from the lack of connectors between the layers of the wall. Therefore, it is 
necessary to tie the masonry layers by making mechanical connectors - at least $4 \mathrm{pcs} / \mathrm{m}^{2}$. Also in this case, it is proposed to use DryFix ties from the Helifix system in the number and spacing as shown in Fig. 19.

Then, the wall should be made in the same way as for the part of the low base using a $4 \mathrm{~cm}$ layer of polystyrene and an external façade mass in the form of mineral plaster painted with facade silicone paint on a fiberglass mesh.

\subsection{Repairing of the flashings}

Due to the increase in the thickness of the outer walls of the west and south facades, all the flashings of these walls must be replaced with new ones. When replacing the flashing on the western wall of the hall, attention should be paid to the formation of appropriate declines (from the building). After removing existing plasters, making a $4 \mathrm{~cm}$ layer of insulation and mineral plaster on the mesh, the thickness of this wall will have increased by about $3.5 \mathrm{~cm}$.

The new roofing works should protrude beyond the face of the wall by at least $40 \mathrm{~mm}$ and should be made in such a way as to protect the façade against rainwater run-off. External window flashings and window sills should be carefully attached.

Flashings should be made in accordance with the relevant construction standard. The sheet should not be placed directly on the concrete or the plaster nor on the materials containing sulphur. A new layer of building paper should be placed under the flashing to ensure the proper insulation. As part of the above repair works, new ventilation grilles should be also installed on the façade.

Damaged flashings on the rest of the building should be improved by sealing them. In addition, new flashings for ceramic cladding located at the entrances to the building should be made.

\subsection{Repairing of the plasters on the façades}

The extent of damage to plastering on the southern and western elevation disqualifies them from further operation. The plaster should be removed from the entire surface of the façade and the wall should be cleaned. Then it should be levelled and the additional protective layer placed in the form of insulating with foamed polystyrene should be placed. Finally, new thinlayer elevation plaster coatings should be made. Flashings should be made in accordance with the relevant construction standard. The sheet should not be placed directly on the concrete or the plaster nor on the materials containing sulphur. A new layer of building paper should be placed under the flashing to ensure the proper insulation. As part of the above repair works, new ventilation grilles should be also installed on the façade.

\subsection{Repairing of the clinker claddings of the retaining wall and basement walls}

Cracked façade cladding in the form of clinker tiles poses a direct hazard to the users of the sports hall. The impact zone around the facility should be marked and excluded from use until the repair is implemented. The repair plan should consist in dismantling the damaged claddings and making new ones. Moreover, due to the significant moisture in the walls observed, it is highly recommended to remove the moisture in a natural way and to perform new flashings on the upper, horizontal surface of the masonry. It is proposed to make new flashings from titanium-zinc sheets of $0.8 \mathrm{~mm}$ thick. 


\subsection{Repairing of the ceramic claddings on the façade and the entrance stairs of the building}

Due to the considerable extent of damage to the entire surface of ceramic claddings and the way they are made, it is necessary to remove these claddings from the entire surface with the mortar on which the cladding was laid. Then the preparation of the surface for renovation is recommended. The surface of exposed walls, both masonry and concrete, should be cleaned. They should not be wet, dirty, greasy or dusty.

In the case of elements of bricks poorly tied with the wall, as well as the presence of highly corroded bricks, they should be removed and the resulting cavities should be refilled. Then, the new ceramic cladding should be laid on the entire surface. Building materials should be intended for outdoor use (frost-proof).

\subsection{Repairing of the roofing}

Leaks in the roof slope are the result of the improper fitting of inlets of rainwater drainage system - see Fig. 12 a), b). These places should be sealed using appropriate sealing materials based on bituminous masses. After making repairs to all roofing elements, it is necessary to remove the existing stains on the ceilings and to paint all the rooms in which stains occur.

\section{Discussion}

Damage caused by the mistakes of contractors are not among the most common and frequent causes of structural failures and collapses [1]. However, it should be noted that not all contractor mistakes imply such a direct hazard. The presented case-study is an example of improper execution of the construction works. The contractor replaced the construction materials adopted in the design and neither consulted nor obtained the consent of the designer to the applied changes. Moreover, the masonry works were carried out contrary to the rules of the civil engineering practise and the technical conditions for this type of building structures. During the construction of the sandwich wall, the basic technological rigor was not used, consisting in the use of connectors between the layers of the wall. All the described damage of the building presented in this case-study paper resulted directly from the performance of the work contrary to the engineering practise and basic knowledge, the arbitrary use of changes in materials, as well as erroneous and carless carrying out of the construction works. Therefore, the contractor incurred the total repair costs of bringing the technical condition of the analysed sports hall to the state consistent with the state-of-the-art practise, engineering knowledge and the applicable technical and construction regulations. The value of construction repair works related to the repair of curtain walls in the variant with the use of fasteners connecting the wall layers as well as the removal of curtain walls and their further reconstruction were similar (the difference was of the order of $10 \%$ of the value). 


\section{Conclusions}

The application of replacement construction materials was not allowed by the designer in the construction work registry as well as in the available design documentation. This constituted an arbitrary changes made by the contractor and construction manager during the execution of construction works and implied further structural damage of the sports hall. The changes concerned mainly the layering of external building walls.

Cracks in the walls of the west façade in their top parts posed a direct hazard to the structural failure. Therefore, these places have been marked and excluded from further operation until these defects are removed. After completion of the necessary repair works, as well as after removal of revealed damage of the structural elements, an acceptance inspection of these works was carried out with the participation of representatives of the contractor, owner and manager of the facility.

Other repair works were carried out in accordance with the recommendations of the authors of the sport hall's expertise $[1,7]$. After a few years of the operation of the sports hall since the execution of the repair works, the building still functions properly. This proves the correctness of the conducted assessment of the causes of damages as well as the effectiveness of renovation works.

\section{References}

1. R. Chmielewski, L. Kruszka, Expertises and technical opinions in the area of building construction (WAT, 2005-2017) [in Polish]

2. S. Bliss, Best Practices Guide to Residential Construction: Materials, Finishes, and Details (John Wiley \& Sons, New Jersey, 2005)

3. W. H. Ransom, Building Failures, Diagnosis \& Avoidance, (E.\& F. Spon, 2nd edition, New York, 1987)

4. S.Y. Harris, Building Pathology, Deterioration, Diagnostics, and Intervention (John Wiley \& Sons, New Jersey, 2001)

5. D. Watt, Building Pathology: Principles and Practice (Wiley-Blackwell, 2 edition, New Jersey, 2008)

6. Z. Janowski, Zasady diagnostyki konstrukcji murowych $w$ pracy rzeczoznawcy budowlanego (Kielce, 1996) [in Polish]

7. R. Chmielewski, L. Kruszka, J. Lalka, Biuletyn WAT, LXV, 4, (2016) [in Polish]

8. P. Aliawdin, W. Simbirkin, W. Epstein, L. Kruszka, Biuletyn WAT, 8, LIII, (2004), pp.147-156) [in Polish]

9. PN-EN 1996 Eurocode 6: Design of Masonry Structures

10. R. Jarmontowicz, J. Sieczkowski, Przegląd budowlany, 86, 7-8 (2015) [in Polish]

11. Polish Construction law: Prawo budowlane (Dz. U. z 2016 r. poz. 290 i Dz. U. z 2016 r. poz. 961) [in Polish]

12. Polish implementing regulation: Rozporzadzenie Ministra Infrastruktury $z$ dnia 12 kwietnia 2002 r. w sprawie warunków technicznych, jakim powinny odpowiadać budynki i ich usytuowanie. [in Polish] 